\title{
Riedel's thyroiditis with invasion of the lungs
}

\author{
MJ WARD, D DAVIES \\ From the Department of Thoracic Medicine, City Hospital, Nottingham
}

Riedel's thyroiditis is characterised by dense fibrosis of the gland, often extending into the strap muscles and adjacent structures in the neck. ${ }^{1}$ The condition is rare, 20 cases being found among 42000 thyroidectomies at the Mayo Clinic. ${ }^{2}$ There is an association between Riedel's thyroiditis and mediastinal fibrosis, sclerosing cholangitis, retroperitoneal fibrosis and periorbital and retroorbital fibrosis. ${ }^{3-5}$ Extension of fibrous tissue from the neck into the lungs has not been described but we now report a case with massive pulmonary fibrosis.

\section{Case report}

A 59-year-old male lace worker presented in 1962 with a small firm lump in the right lobe of the thyroid. Thyroid function tests were normal. At operation the gland was hard, white, and adherent to the strap muscles. Biopsy of the isthmus showed dense fibrous tissue and patchy infiltration with lymphocytes, plasma cells, and eosinophils but no recognisable thyroid structure (fig 1a). This was considered to be Riedel's thyroiditis. No further operative or other measures were taken. A chest radiograph was reported to show pleural thickening over the lung apices.

Shortness of breath began to trouble him soon after 1962. It gradually became more severe and was accompanied by a dry cough. Mild enlargement of the thyroid gland persisted. A chest radiograph in 1968 showed large opacities in the upper parts of both lungs but the cause was not investigated. By 1978 he could only walk slowly

Address for reprint requests: Dr D Davies, Department of Thoracic Medicine, City Hospital, Hucknall Road, Nottingham NG5 1PB. because of shortness of breath. On examination his general condition was good. The thyroid gland was no longer palpable and the trachea was central. There was dullness and bronchial breathing over both upper lung zones. A radiograph showed dense homogenous opacities occupying the upper half of the right and the upper third of the left hemithorax (fig 2). Tomograms showed the upper lobe bronchi to be running into the opaque areas and the lobes showed no aerated tissue.

The forced vital capacity was $2 \cdot 251$ (61\% of predicted); the forced expiratory volume in one second was 1.351 ( $54 \%$ of predicted); the total lung capacity was 3.631 (55\% of predicted) and the residual volume $1.431(57 \%$ of predicted). Bronchoscopy showed a normal trachea and main bronchi. Both upper lobe bronchi and the middle lobe bronchus were narrowed by external pressure. Immobile bubbles in the right upper lobe bronchus showed that it was not ventilating. Biopsy of the right upper lobe bronchus showed some peribronchial fibrosis. Percutaneous needle biopsy of the lung through the second right anterior intercostal space produced solid tissue. Histology showed fibrous tissue which was identical with the thyroid biopsy of 1962 except for the inclusion of carbon (fig 1b). By this time the level of thyroid stimulating hormone had risen to $40 \mathrm{mu} / 1$ (normal < $7 \mathrm{mu} / \mathrm{l}$ ) and the free thyroxine index had fallen to 49 (normal 70-125). Thyroid autoantibodies were absent and he did not improve with thyroxine.

In 1980 at the age of 77 years he developed cardiac failure with breathlessness at rest and orthopnoea. $\mathrm{He}$ improved on diuretics and he is now comfortable at rest $\times$ but continues to be very short of breath on exertion.

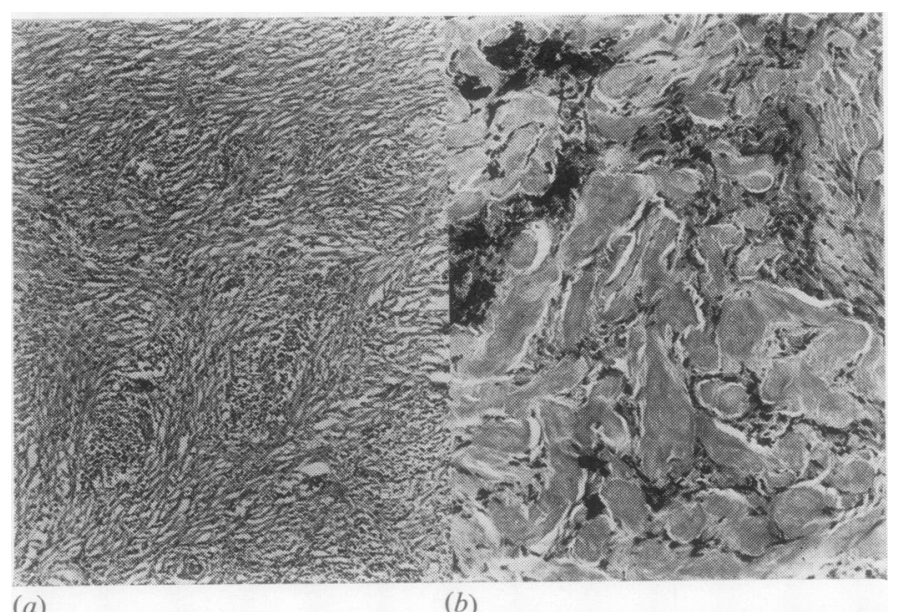

Fig 1 (a) Biopsy of thyroid gland showing the absence of acini, fibrosis and infiltration with lymphocytes, plasma cells, and eosinophils. Original magnification $\times 126$. (b) Needle biopsy of lung. There is no recognisable lung structure but there is dense fibrous tissue incoporating carbon. Original magnification $\times 315$. 


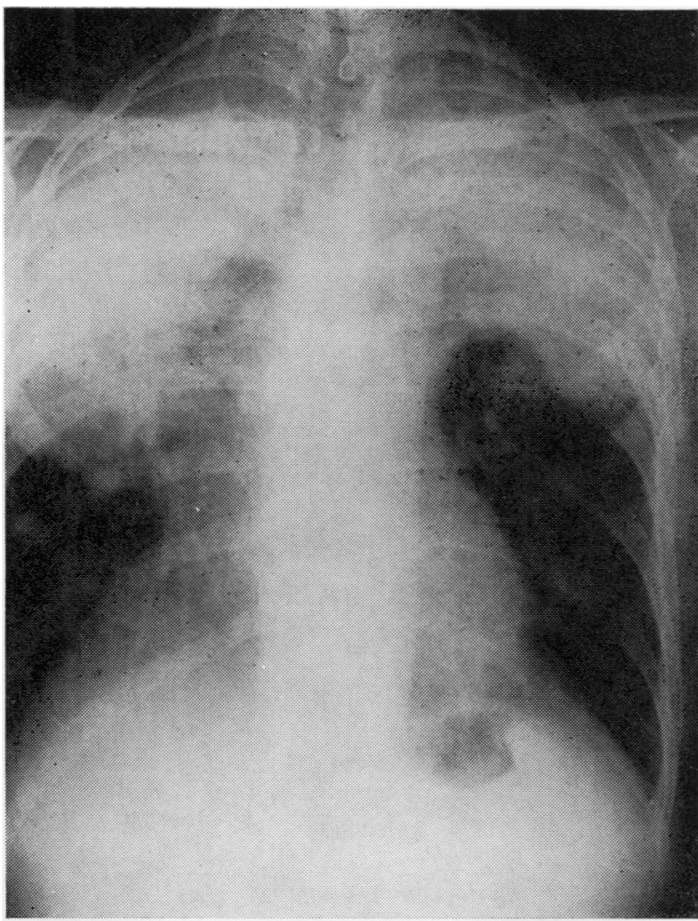

Fig 2 Chest radiograph in 1978 showing large dense opacities occupying the upper part of the thorax.

\section{Discussion}

This case fulfils the criteria for a diagnosis of Riedel's thyroiditis. ${ }^{2}$ The fibrosis destroyed the gland without a giant cell or granulomatous reaction and extended into adjacent structures. These features distinguish it from Hashimoto's thyroiditis and granulomatous thyroiditis. Thyroid antibodies were absent and the patient eventually developed biochemical evidence of hypothyroidism. He had not been on any medication known to cause tissue fibrosis and did not have radiotherapy. Barium swallow showed a normal oesophagus without reflux. Though his HLA tissue type was B27, radiographs of the spine and sacroiliac joints were normal, so this is not lung fibrosis complicating ankylosing spondylitis. ${ }^{6}$

The microscopical appearances of the goitre and material from the upper lobe of the lung are similar, showing fibrosis and infiltration by lymphocytes, plasma cells, and eosinophils. A diagnostic feature of Riedel's thyroiditis is that the fibrosis ixtends beyond the thyroid and in this case it invades the lungs. The shape of the opacities (fig 2) indicates growing lesions rather than a shrinking fibrotic process within the lungs. The tomograms suggest that alveolar tissue has been destroyed by the advancing fibrosis and that the lung has not been merely pushed aside. Confirmation of this comes from finding carbon in the needle biopsy.

The earlier radiographs are not available but the reports indicate that spread of fibrosis into the thorax had already begun in 1962 and progressed over the next 16 years.

We are grateful to Dr $\mathbf{J}$ Johnson for the photomicrographs.

\section{References}

${ }^{1}$ Riedel BMCL. Die chronische, Zur Bilding eisenharter Tumoven fuhrends Extzunding der Schilddruse. Vehr Dtsch Ges Chir 1896;25:101-5.

2 Woolner LB, McGrahey W, Beahrs OH. Invasive fibrous thyroditis (Riedel's struma). J Clin Endocrinol 1957;17: 201-20.

${ }^{3}$ Hache L, Woolner LB, Bernatz P. Idiopathic fibrous mediastinitis. Dis Chest 1962;41:9-25.

4 Gleeson MH, Taylor S. Multifocal fibrosclerosis. Proc $R$ Soc Med 1970;63:1309-11.

${ }^{5}$ Amorosa LF, Shear K, Spiera H. Multifocal fibrosis involving the thyroid, face, and orbits. Arch Intern Med 1976;136:221-3.

- Davies D. Ankylosing spondylitis and lung fibrosis. $Q J$ Med 1972;41:395-417. 